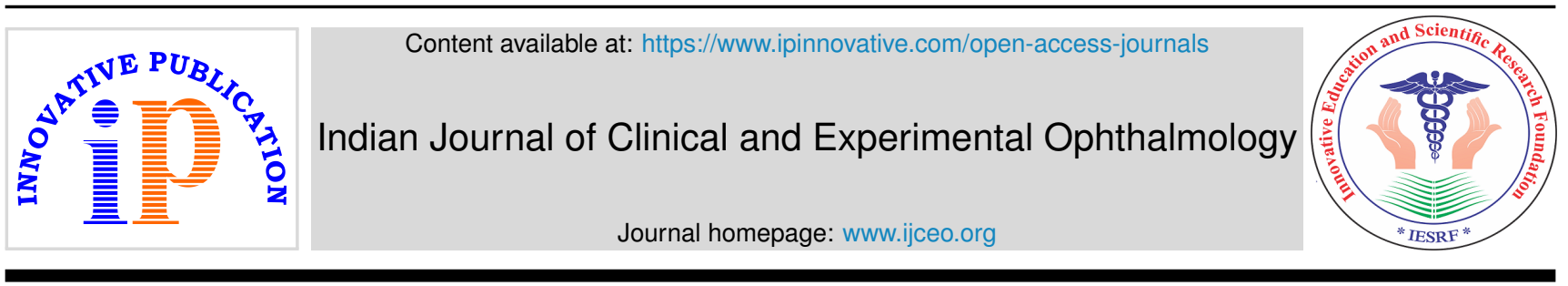

\title{
Editorial
}

\section{SARS-CoV-2 Virus: A new addition to the checklist of investigations for post fever retinitis?}

\author{
Hannah Ranjee Prasanth ${ }^{1} *$, Nagesha $\mathrm{CK}^{2}$ \\ ${ }^{1}$ Dept. of Ophthalmology, Pondicherry Institute of Medical Sciences, Kalapet, Puducherry, India \\ ${ }^{2}$ Dept. of Vitreo-Retina, BW Lions Superspeciality Eye Hospital, Bangalore, Karnataka, India
}

\section{A R T I C L E I N F O}

Article history:

Received 08-03-2021

Accepted 22-03-2021

Available online 01-04-2021
(C) This is an open access article distributed under the terms of the Creative Commons Attribution License (https://creativecommons.org/licenses/by/4.0/) which permits unrestricted use, distribution, and reproduction in any medium, provided the original author and source are credited.
Post fever retinitis (PFR) includes all the retinal manifestations typically seen 4-8 weeks following infectious febrile illness caused by bacteria, viruses, and parasites. The most commonly implicated agents are Dengue, Chikungunya, West-Nile virus, Rickettsia, HIV and Herpes family. Often the retinal manifestations are similar, posing a dilemma during evaluation of the causative agent. On the other hand, the majority of PFR are self-limiting, with a good prognosis, with or without treatment. $^{1}$

Many patho-mechanisms have been postulated in the causation of retinitis post febrile episode. Direct invasion by viruses, immune-mediated endothelial damage, and direct immune complex deposits in the vascular lumen are thought to cause hypoxia and tissue destruction. On the contrary, investigations to demonstrate a causative agent from ocular specimens often fail. This creates confusion over the exact mechanism of injury and hence possible target interventions.

Coronaviruses are viruses that are known to cause diseases in birds and animals. They rose to public prominence recently with the outbreak of the SARSCoV-2 variant which can cause life-threatening respiratory illness. $^{2,3}$ Of the 7 types of coronaviruses that infect humans, SARS-Co-V belongs to the beta-coronavirus

\footnotetext{
* Corresponding author.

E-mail address: drranjee@hotmail.com (H. R. Prasanth).
}

family and are capable of producing pulmonary and also ocular manifestations in humans and animal models ranging from simple conjunctivitis to sight-threatening retinochoroiditis and optic neuritis. ${ }^{4}$

A metallopeptidase ACE-2 protein is a functional receptor for coronavirus to invade host cells. ACE receptors are well expressed in the conjunctiva and retina raising the possibility of direct invasion into the tissue through the ocular surface or hematogenous entry of the virus. It is also postulated that SARS-CoV-2 could lead to complementmediated endothelial dysfunction, microvascular damagecausing circulatory disturbance, and ischemic events in different organs of the body, including the eye. ${ }^{5}$

Since the beginning of the COVID-19 pandemic secondary to the SARS-CoV-2 virus, ophthalmological manifestations have emerged into the limelight periodically. ${ }^{6}$ Marinho et al., ${ }^{7}$ first described retinal manifestations of SARS-CoV-2 infection in 19 patients as hyperreflective lesions affecting ganglion cells and inner plexiform layers in the OCT sections. Additionally, 4 patients displayed cotton wool spots at retinal arcades along with microangiopathy changes. Casagrande et al., ${ }^{8}$ detected SARS-CoV-2 viral RNA in 3 samples of 14 retinae biopsied from patients deceased due to COVID-19. Apart from this, sporadic case reports of vascular occlusions secondary to hypercoagulopathy have been described post-SARS-CoV-2 infection implicating its role in vasculotoxic and neurotoxic pathways. $^{9,10}$ 
Though SARS-CoV-2 has been implicated in the causation of polyneuritis, Guillain-Barre Syndrome, meningitis and encephalomyelitis; there is very little recent literature documenting retinal involvement, though the potential to cause retinal damage is very much speculative. $^{11}$ It was learned from experimental animal models that these coronavirus families could potentially cause pyogranulomatous uveitis, choroiditis, retinal vasculitis, and optic neuritis. ${ }^{12}$ Similar observations are not seen in human infections.

Post fever retinitis seems to be a predominantly selflimiting acute inflammation of the retina. They often present with involvement of inner retina layers with overlying vitreous cells without involvement of choroidal layers. The SARS-CoV-2 virus has theoretical potential to involve inner retinal layers as supported by recent literature, and this addition into the armamentarium of PFR workup is warranted. Given sparse evidence of retinal manifestations by SARS-CoV-2, its role in the causation of retinitis should be borne in mind as one of the possible differentials during the evaluation of PFR.

The number of COVID-19 positive cases is rising but there has not been a proportional increase in the number of cases with retinal involvement reported in literature to support SARS-CoV-2 predilection for the retina. This may be due to less tropism of the virus to the retina or because those with retinal involvement did not test for the SARSCoV-2 virus. Having strong suspicion not only rules out the possibility, but also helps in effectively quarantining the patient, if the results turn out to be positive. Though the speculations are far from reality, evaluating the actual incidence and its causation would help fill the gaps in the existing literature about SARS-CoV-2 and PFR.

\section{References}

1. Mahendradas P, Kawali A, Luthra S, Srinivasan S, Curi A, Maheswari $\mathrm{S}$, et al. Post-fever retinitis - Newer concepts. Indian J Ophthalmol. 2020;68(9):1775-86

2. Salata C, Calistri A, Parolin C, Palù G. Coronaviruses: a paradigm of new emerging zoonotic diseases. Pathog Dis. 2019;77(9).
3. Coronavirus disease 2019 (COVID-19) situation report 32.

4. Wang Y, Detrick B, Yu ZX, Zhang J, Chesky L, Hooks JJ, et al. The role of apoptosis within the retina of coronavirus-infected mice. Invest Ophthalmol Vis Sci. 2000;41(10):3011-8.

5. Seah I, Agrawal R. Can the Coronavirus Disease 2019 (COVID-19) Affect the Eyes? A Review of Coronaviruses and Ocular Implications in Humans and Animals. Ocul Immunol Inflamm. 2020;28(3):391-5.

6. Wu P, Duan F, Luo C. Characteristics of Ocular Findings of Patients With Coronavirus Disease 2019 (COVID-19. JAMA Ophthalmol. 2020;138(5):575-8.

7. Marinho PM, Marcos AAA, Romano AC, Nascimento H, Belfort R. Retinal findings in patients with COVID-19. Lancet. 2020;395(10237):1610.

8. Casagrande M, Fitzek A, Püschel K, Aleshcheva G, Schultheiss HP, Berneking L, et al. Detection of SARS-CoV-2 in Human Retinal Biopsies of Deceased COVID-19 Patients. Ocul Immunol Inflamm. 2020;28(5):721-5.

9. Dumitrascu OM, Volod O, Bose S, Wang Y, Biousse V, Lyden PD, et al. Acute ophthalmic artery occlusion in a COVID-19 patient on apixaban. J Stroke Cerebrovasc Dis. 2020;29(8):104982.

10. Llitjos JF, Leclerc M, Chochois C, Monsallier JM, Ramakers M, Auvray M, et al. High incidence of venous thromboembolic events in anticoagulated severe COVID-19 patients. J Thromb Haemost. 2020;18(7):1743-6.

11. Moriguchi T, Harii N, Goto J. A first case of meningitis/encephalitis associated with SARS-coronavirus-2. Int J Infect Dis. 2020;94:55-8.

12. Doherty MJ. Ocular manifestations of feline infectious peritonitis. $J$ Am Vet Med Assoc. 1971;159(4):417-24.

\section{Author biography}

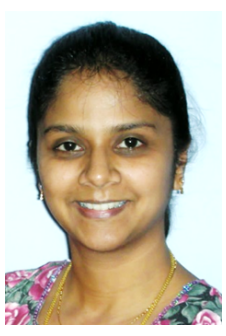

Hannah Ranjee Prasanth, Professor

Nagesha CK, Consultant

Cite this article: Prasanth HR, Nagesha CK. SARS-CoV-2 Virus: A new addition to the checklist of investigations for post fever retinitis?. Indian J Clin Exp Ophthalmol 2021;7(1):177-178. 